Institute of $\mathbf{F}_{\text {ood and }} \mathbf{A}$ gricultural $\mathbf{S}_{\text {ciences }}$

\title{
Tobacco Budworm, Heliothis virescens (Fabricius) (Insecta: Lepidoptera: Noctuidae) ${ }^{1}$
}

J. L. Capinera ${ }^{2}$

\section{Distribution}

The tobacco budworm, Heliothis virescens (Fabricius), is a native species and is found throughout the eastern and southwestern United States, though it is also known from California. It generally overwinters successfully only in southern states. However, it occasionally survives cold climates in greenhouses and other sheltered locations. Tobacco budworm disperses northward annually, and can be found in New England, New York, and southern Canada during the late summer. It also occurs widely in the Caribbean, and sporadically in Central and South America.

\section{Life Cycle and Description}

Moths emerge March through May in southern states, followed by four to five generations through the summer, with overwintering commencing September through November. Four generations have been reported from northern Florida (Chamberlin and Tenhet 1926) and North Carolina (Neunzig 1969), and at least five from Louisiana (Brazzel et al. 1953). Moths have been collected in New York July through

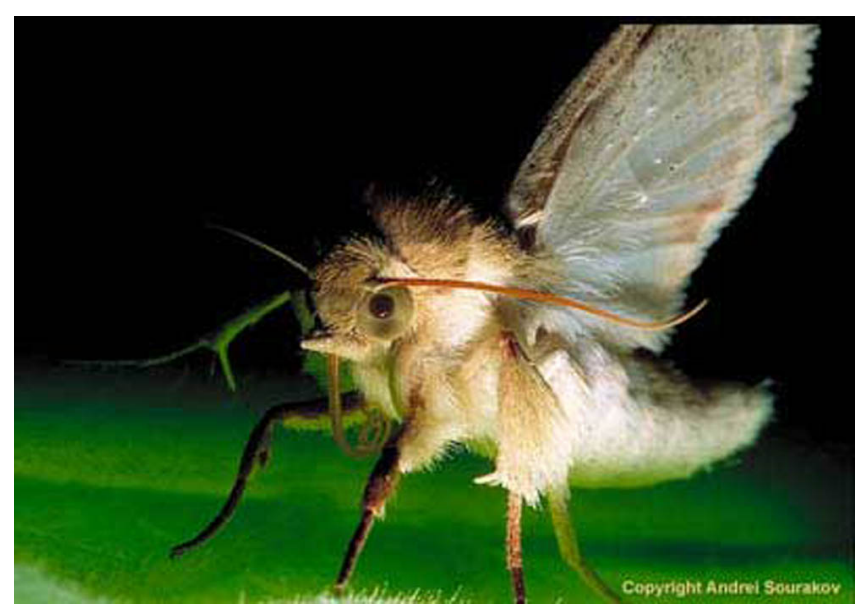

Figure 1. A closeup of an adult tobacco budworm, Heliothis virescens (Fabricius). Credits: Andrei Sourakov, USDA

September, but at such northern latitudes it is not considered to be a pest (Chapman and Lienk 1981). This species overwinters in the pupal stage.

\section{Eggs}

Eggs are deposited on blossoms, fruit, and terminal growth. The eggs are spherical, with a flattened base. They measure 0.51 to $0.60 \mathrm{~mm}$ in width and 0.50 to $0.61 \mathrm{~mm}$ in height. Eggs initially

1. This document is EENY-219, one of a series of Featured Creatures from the Entomology and Nematology Department, Florida Cooperative Extension Service, Institute of Food and Agricultural Sciences, University of Florida. Published: July 2001. This document is also available on Featured Creatures Website at http://creatures.ifas.ufl.edu. Please visit the EDIS Website at http://edis.ifas.ufl.edu. Additional information on these organisms, including many color photographs, is available at the Entomology and Nematology Department website at http://entnemdept.ifas.ufl.edu/.

2. J. L. Capinera, professor/chairman, Entomology and Nematology Department, Cooperative Extension Service, Institute of Food and Agricultural Sciences, University of Florida, Gainesville, FL 32611.

The Institute of Food and Agricultural Sciences is an equal opportunity/affirmative action employer authorized to provide research, educational information and other services only to individuals and institutions that function without regard to race, color, sex, age, handicap, or national origin. For information on obtaining other extension publications, contact your county Cooperative Extension Service office. Florida Cooperative Extension Service/Institute of Food and Agricultural Sciences/University of Florida/Christine Taylor Waddill, Dean. 
are whitish to yellowish white in color, but turn gray as they age. Narrow ridges radiate from the tip of the egg, and number 18 to 25 in number. Eggs of tobacco budworm are nearly indistinguishable from those of corn earworm, Heliocoverpa zea. At high magnification, however, the primary ribs of tobacco budworm eggs can be observed to terminate before they reach the rosette of cells surrounding the micropyle; in corn earworm at least some primary ribs extend to the rosette (Bernhardt and Phillips 1985). Females normally produce from 300 to 500 eggs, but 1000 to 1500 eggs per female have been reported from larvae cultured on artificial diet at cool temperatures (Fye and McAda 1972).

\section{Larvae}

Tobacco budworm larvae have five to seven instars, with five or six most common. Head capsule widths for larvae that develop through five instars measure 0.26-0.31, 0.46-0.54, 0.92-0.99, 1.55-1.72, 2.38-2.87 $\mathrm{mm}$ for instars one through five respectively. Larval lengths are 1.1-4.0, 4.2-8.0, 8.7-14.7, 18.5-25.6, and 23.3-35.6 $\mathrm{mm}$ for these same instars. Head capsule widths for larvae that develop through six instars measure $0.26-0.31,0.36-0.53$, $0.72-0.85,1.12-1.25,1.60-1.72$, and $2.40-2.82 \mathrm{~mm}$ for instars one through six respectively. Larval lengths are 1.4-4.1, 3.0-7.0, 7.5-9.2, 12.0-15.8, 19.5-24.3, and 25.5-36.0 mm for these same instars.

Development time was studied by Fye and McAda (1972) at various temperatures. When cultured at $20^{\circ} \mathrm{C}$, development required about 4.6, 2.6, 3.1, 3.7, 10.1, and 9.8 days for instars one through six, respectively. At $25^{\circ} \mathrm{C}$, larval development times were $3.1,2.0,1.9,2.1,5.7$, and 2.5 days, respectively.

Young larvae are yellowish or yellowish green in color with a yellowish brown head capsule. Later instars are greenish with dorsal and lateral whitish bands, and with a brown head capsule. Many of the bands may be narrow or incomplete, but a broad, lateral subspiracular band is usually pronounced. Body color is variable, and pale green or pinkish forms, or dark reddish or maroon forms are sometimes found. Larvae are very similar to corn earworm. As is the case with corn earworm, the body bears numerous black thorn-like microspines. These spines give the body a rough feel when touched.

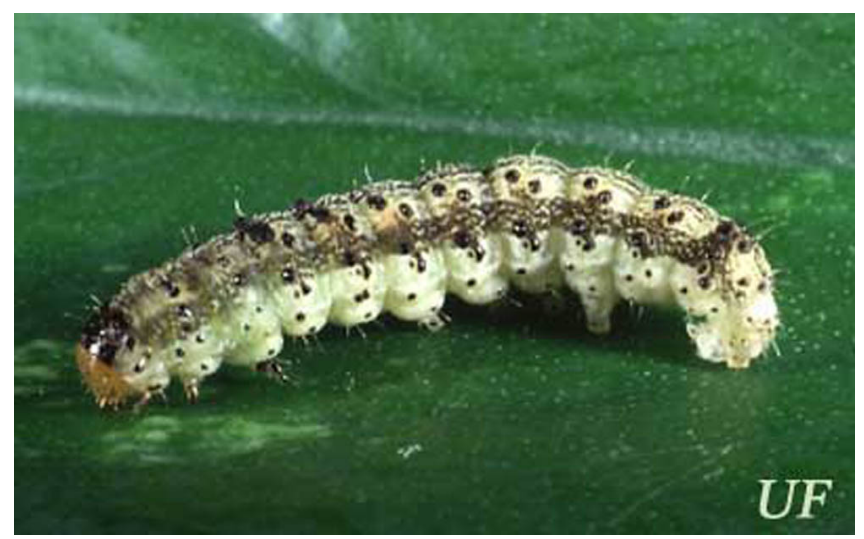

Figure 2. Credits: John Capinera, University of Florida

Early instars are difficult to separate from corn earworm; Neunzig (1964) gives distinguishing characteristics. Starting with the third instar, close examination reveals tubercles with small thorn-like microspines on the first, second, and eighth abdominal segments that are about half the height of the tubercles. In corn earworm the microspines on the tubercles are absent or up to one-fourth the height of the tubercle. Larvae exhibit cannibalistic behavior starting with the third or fourth instar, but are not as aggressive as corn earworm.
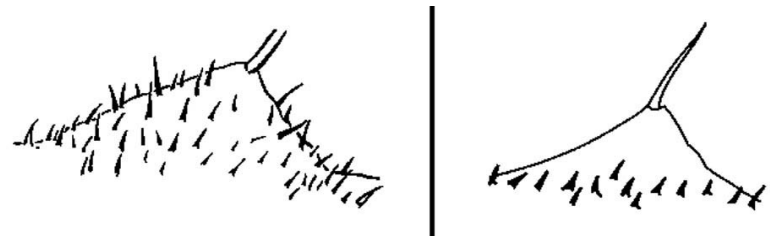

Figure 3. Tobacco budworm tubercle with microspines (left); Corn earworm tubercle with microspines (right).

\section{Pupa}

Pupation occurs in the soil. Pupae are shiny reddish brown in color, becoming dark brown prior to emergence of the adult. The pupa averages $18.2 \mathrm{~mm}$ in length and $4.7 \mathrm{~mm}$ in width. Duration of the pupal stage is reported to be about 22 days at $20^{\circ} \mathrm{C}, 13.0$ days at $25^{\circ} \mathrm{C}$, and 11.2 days at $30^{\circ} \mathrm{C}$. Diapause is initiated by either low temperatures or short day length (Henneberry et al. 1993, Henneberry 1994). 


\section{Adults}

The moths are brownish in color, and lightly tinged with green. The front wings are crossed transversely by three dark bands, each of which is often accompanied by a whitish or cream-colored border. Females tend to be darker in color. The hind wings are whitish, with the distal margin bearing a dark band. The moths measure 28 to $35 \mathrm{~mm}$ in wing span. The pre- oviposition period of females is about two days in length. Longevity of moths is reported to range from 25 days when held at $20^{\circ} \mathrm{C}$, to 15 days at $30^{\circ} \mathrm{C}$. A sex pheromone has been identified (Tumlinson et al. 1975).

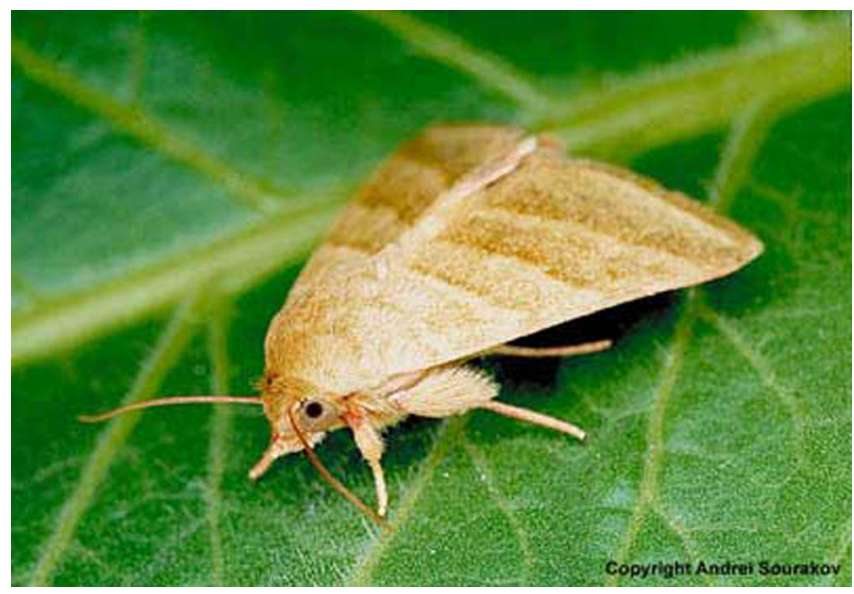

Figure 4. An adult tobacco budworm, Heliothis virescens (Fabricius). Credits: Andrei Sourakov, USDA

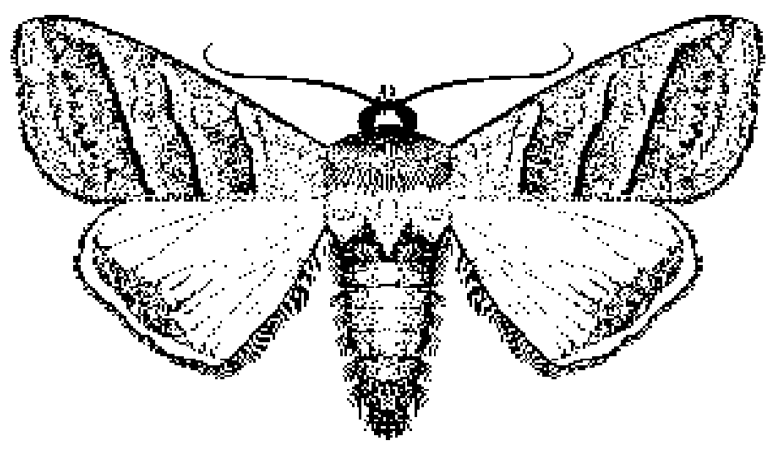

Figure 5.

Biology of tobacco budworm is given by Neunzig (1969) and Brazzel et al. (1953). The larva is included in keys by Okumura (1962) and Oliver and Chapin (1981); the latter publication also pictures the adult stage. Larvae are readily cultured on bean-based rearing media or other diets (King and Hartley 1985).

\section{Host Plants}

Tobacco budworm is principally a field crop pest, attacking such crops as alfalfa, clover, cotton, flax, soybean, and tobacco. However, it sometimes attacks such vegetables as cabbage, cantaloupe, lettuce, pea, pepper, pigeon pea, squash, and tomato, especially when cotton or other favored crops are abundant. Tobacco budworm is a common pest of geranium and other flower crops such as ageratum, bird of paradise, chrysanthemum, gardenia, geranium, petunia, mallow, marigold, petunia, snapdragon, strawflower, verbena, and zinnia.

Weeds serving as a host for larvae include beardtongue, Penstemon laevigatus; beggarweed, Desmodium spp.; bicolor lespedeza, Lespedeza bicolor; black medic, Medicago lupulina; cranesbill, Geranium dissectum; deergrass, Rhexia spp.; dock, Rumex spp., groundcherry, Physalis spp.; Japanese honeysuckle, Lonicera japonica; lupine, Lupinus spp.; morningglory, Ipomoea spp.; a morningglory, Jacquemontia tamnifolia; passionflower, Passiflora sp.; prickly sida, Sida spinosa; sunflower, Helianthus spp.; toadflax, Linaria canadensis; and velvetleaf, Abutilon theophrasti (Brazzel et al. 1953, Neunzig 1963, Graham and Robertson 1970, Roach 1975, Harding 1976, Stadelbacher 1981, Pair 1994, Sudbrink and Grant 1995). In Georgia, Barber (1937) determined that tobacco budworm developed principally on toadflax during April and May for one to two generations, followed by one generation on deergrass during June and July and two to three generations on beggarweed during July through October. In Mississippi, cranesbill was identified as the key early season host plant (Stadelbacher 1981). In southern Texas cotton is the principal host, but such weeds as wild tobacco, Nicotania repanda; vervain, Verbena neomexicana; ruellia, Ruellia runyonii; and mallow, Aubitilon trisulcatum, are important hosts early or late in the year (Graham et al. 1972).

In cage tests and field studies conducted in Florida and which did not include cotton, tobacco was more highly preferred than other field crops and vegetables, but cabbage, collards, okra, and tomato were attacked (Martin et al. 1976). 


\section{Damage}

Larvae bore into buds and blossoms (the basis for the common name of this insect), and sometimes the tender terminal foliar growth, leaf petioles, and stalks. In the absence of reproductive tissue, larvae feed readily on foliar tissue. Neunzig (1969), infested tobacco with both tobacco budworm and corn earworm, and observed very similar patterns and levels of injury by these closely related species. Entry of larvae into fruit increases frequency of plant disease. Research in southern Arkansas tomato fields indicated that although tobacco budworm was present from May through July, they were not nearly as abundant or damaging as corn earworm (Roltsch and Mayse 1984).

\section{Natural Enemies}

Numerous general predators have been observed to feed upon tobacco budworm. Among the most common are Polistes spp. wasps (Hymenoptera: Vespidae); bigeye bug, Geocoris punctipes (Say) (Hemiptera: Lygaeidae); damsel bugs, Nabis spp. (Hemiptera: Nabidae); minute pirate bugs, Orius spp. (Hemiptera: Anthocoridae), and spiders.

Several parasitoids also have been observed, and high levels of parasitism have been reported (Lewis and Brazzel 1968, Tingle et al. 1994). The egg parasitoid Trichogramma pretiosum Riley (Hymenoptera: Trichogrammatidae) can be effective in vegetable crops. Other important parasitoids are Cardiochiles nigriceps Viereck in vegetables and Cotesia marginiventris(Cresson) in other crops (both Hymenoptera: Braconidae). Effectiveness of the parasitoids varies among crops (Martin et al. 1981). Other species known from tobacco budworm include Archytas marmoratus (Townsend) (Diptera: Tachinidae); Meteorus autographae Muesebeck (Hymenoptera: Braconidae); Campoletis flavicincta (Ashmead), C. perdistinctus (Viereck), C. sonorensis (Cameron), Netelia sayi (Cushman) and Pristomerus spinator (Fabricius) (all Hymenoptera: Ichneumonidae).

Pathogens are also known to inflict mortality. Among the known pathogens are microsporidia, Nosema spp., fungi such as Spicaria rileyi, and nuclear polyhedrosis viruses. In a study conducted in

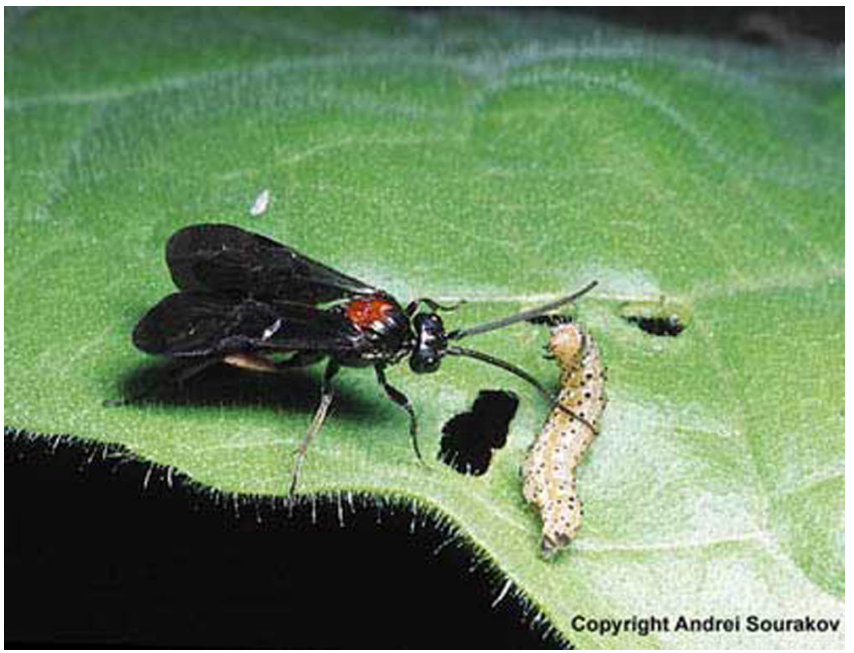

Figure 6. The wasp parasitoid Cardiochiles nigriceps Viereck, approaches a potential host, an adult tobacco budworm, Heliothis virescens (Fabricius). Credits: Andrei Sourakov, USDA

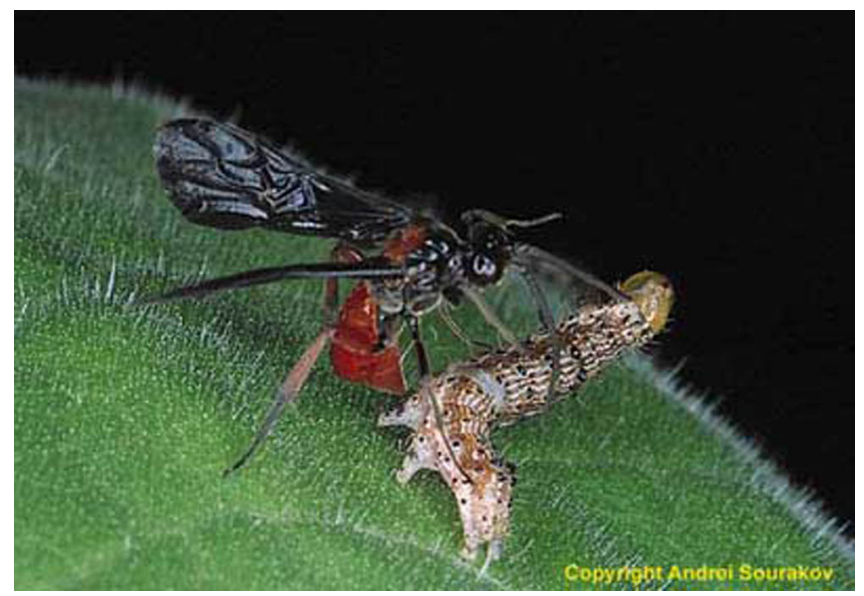

Figure 7. The wasp parasitoid Cardiochiles nigriceps Viereck, stinging an adult tobacco budworm, Heliothis virescens (Fabricius). Credits: Andrei Sourakov, USDA

South Carolina, Spicaria was a more important mortality agent than natural incidence of virus, and was considered to be one of the most important natural mortality agents (Roach 1975).

\section{Management}

\section{Sampling}

Large cone-shaped wire traps baited with sex pheromone lures are commonly used to capture tobacco budworm moths (Hartstack et al. 1979). Smaller bucket traps can capture these moths, but they are not very efficient (Lopez et al. 1994). 


\section{Insecticides}

Foliar insecticides are commonly used in crops where tobacco budworm damage is likely to occur. However, destruction of beneficial organisms often results, and this is thought to exacerbate budworm damage. Also, resistance to insecticides is widespread, particularly in crops where pyrethroid use is frequent (Kanga et al. 1995, Greenstone 1995). Larvae will also consume bait formulated from cornmeal and insecticide (Creighton et al. 1961).

\section{Insect Management Guide for Field Crops \\ Insect Management Guide for Vegetables \\ Insect Management Guide for Ornamentals}

\section{Cultural Techniques}

Early season destruction of weeds with herbicide or mowing, or destruction of larvae on the weeds by treatment with insecticides, can reduce tobacco budworm population size later in the year (Bell and Hayes 1994, Snodgrass and Stadelbacher 1994).

\section{Biological Control}

The microbial insecticide Bacillus thuringiensis is effective against budworm (Johnson 1974, Stone and Sims 1993). Heliothis nuclear polyhedrosis virus has been used effectively to suppress tobacco budworm on field crops (Andrews et al. 1975) and on early season weed hosts (Hayes and Bell 1994). Tobacco budworm also is susceptible to nuclear polyhedrosis virus from alfalfa looper, Autographa californica (Speyer) (Vail et al. 1978, Bell and Romine 1980). Release of Trichogramma egg parasitoids has been shown to be beneficial in some vegetable crops (Martin et al. 1976).

\section{Host Plant Resistance}

Although there is little evidence for natural resistance to tobacco budworm among many crops, cotton is being genetically engineered to express resistance (Benedict et al. 1996). Enhanced resistance to larval survival by cotton should result in lower insect pressure on nearby vegetable crops.

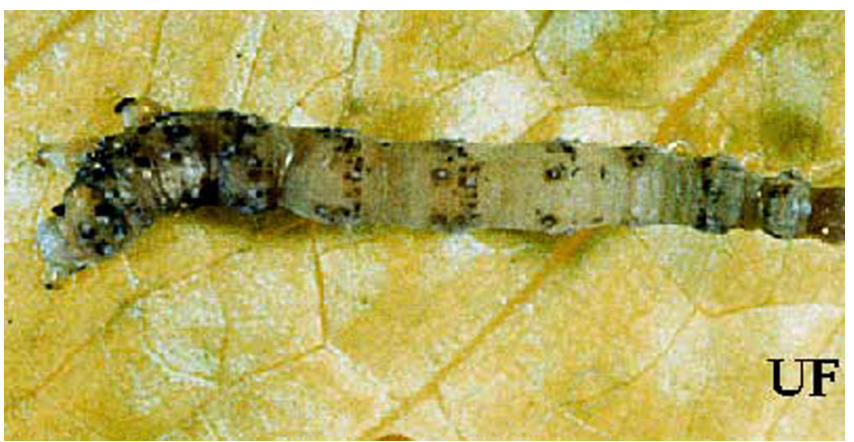

Figure 8. Looper infected with a nuclear polyhedrosis virus. Credits: J. L. Capinera, University of Florida

\section{Selected References}

Andrews, G.L., F.A. Harris, P.P. Sikorowski, and R.E. McLaughlin. 1975. Evaluation of Heliothis nuclear polyhedrosis virus in a cottonseed oil bait for control of Heliothis virescens and H. zea on cotton. J. Econ. Entomol. 68:87-90.

Barber, G.W. 1937. Seasonal availability of food plants of two species of Heliothis in eastern Georgia. J. Econ. Entomol. 30:150-158.

Bell, M.R. and J.L. Hayes. 1994. Areawide management of cotton bollworm and tobacco budworm (Lepidoptera: Noctuidae) through application of a nuclear polyhedrosis virus on earlyseason alternate hosts. J. Econ. Entomol. 87:53-57.

Bell, M.R. and C.L. Romine. 1980. Tobacco budworm field evaluation of microbial control in cotton using Bacillus thuringiensis and a nuclear polyhedrosis virus with a feeding adjuvant. J. Econ. Entomol. 73:427-430.

Benedict, J.H., E.S. Sachs, D.W. Altman, W.R. Deaton, R.J. Kohel, D.R. Ring, and S.A. Berberich. 1996. Field performance of cottons expressing transgenic CryIA insecticidal proteins for resistance to Heliothis virescens and Helicoverpa zea (Lepidoptera: Noctuidae). J. Econ. Entomol. 89:230-238.

Bernhardt, J.L. and J.R. Phillips. 1985. Identification of eggs of the bollworm, Heliothis zea (Boddie), and the tobacco budworm, Heliothis virescens (F.). Southwestern Entomol. 10:236- 238.

Brazzel, J.R., L.D. Newsom, J.S. Roussel, C. Lincoln, F.J. Williams, and G. Barnes. 1953. 
Bollworm and tobacco budworm as cotton pests in Louisiana and Arkansas. Louisiana Agric. Exp. Stn. Tech. Bull. 482.47 pp.

Capinera, J.L.2001. Handbook of Vegetable Pests. Academic Press, San Diego. 729 pp.

Chamberlin, F.S. and J.N. Tenhet. 1926. The seasonal history and food habits of the tobacco budworm, Heliothis virescens Fab., in the southern tobacco-growing region. J. Econ. Entomol. 19:611-614.

Chapman, P.J. and S.E. Lienk. 1981. Flight periods of adults of cutworms, armyworms, loopers and others (family Noctuidae) injurious to vegetable and field crops. New York Agric. Exp. Stn. Search: Agric. Bull. 14. 43 pp.

Creighton, C.S., W.S. Kinard, and N. Allen. 1961. Effectiveness of Bacillus thuringiensis and several chemical insecticides for control of budworms and hornworms on tobacco. J. Econ. Entomol. 54:1112-1114.

Fye, R.E. and W.C. McAda. 1972. Laboratory studies on the development, longevity, and fecundity of six lepidopterous pests of cotton in Arizona. USDA Tech. Bull. 1454. 73 pp.

Graham, H.M. and O.T. Robertson. 1970. Host plants of Heliothis virescens and H. zea (Lepidoptera: Noctuidae) in the lower Rio Grande Valley, Texas. Ann. Entomol. Soc. Am. 63:1261-1265.

Greenstone, M.H. 1995. Bollworm or budworm? Squashblot immunoassay distinguishes eggs of Helicoverpa zea and Heliothis virescens (Lepidoptera: Noctuidae). J. Econ. Entomol. 88:213- 218.

Harding, J.A. 1976. Heliothis spp.: seasonal occurrence, hosts and host importance in the lower Rio Grande Valley. Environ. Entomol. 5:666-668.

Hartstack, A.W., J.A. Witz, and D.R. Buck. 1979. Moth traps for the tobacco budworm. J. Econ. Entomol. 72:519-522.

Hayes, J.L. and M. Bell. 1994. Evaluation of early-season baculovirus treatment for suppression of Heliothis virescens and Helicoverpa zea (Lepidoptera:
Noctuidae) over a wide area. J. Econ. Entomol. 87:58-66.

Henneberry, T.J. 1994. Effects of temperature on tobacco budworm (Lepidoptera: Noctuidae) pupal diapause, initiation and final stage of movement of stemmatal eyespots and adult emergence.

Southwestern Entomol. 19:329-333.

Henneberry, T.J., G.D. Butler, Jr., and D.L. Coudriet. 1993. Tobacco budworm (Lepidoptera: Noctuidae): effects of temperature and photoperiod on larval and pupal development, larval mortality and induction of pupal diapause. Southwestern Entomol. 18:269-279.

Johnson, A.W. 1974. Bacillus thuringiensis and tobacco budworm control on flue-cured tobacco. J. Econ. Entomol. 67:755-759.

Kanga, L.H.B., F.W. Plapp, Jr., G.W. Elzen, M.L. Wall, and J.D. Lopez, Jr. 1995. Monitoring for resistance to organophosphorus, carbamate, and cyclodiene insecticides in tobacco budworm adults (Lepidoptera: Noctuidae). J. Econ. Entomol. 88:1144-1149.

King, E.G. and G.G. Hartley. 1985. Heliothis virescens. Pages 323-328 in P. Singh and R.F. Moore (eds.). Handbook of Insect Rearing Vol. II. Elsevier, New York.

Lewis, W.J. and J.R. Brazzel. 1968. A three-year study of parasites of the bollworm and the tobacco budworm in Mississippi. J. Econ. Entomol. 61:673-676.

Lopez, Jr., J.D., J.L. Goodenough, and K.R. Beerwinkle. 1994. Comparison of two sex pheromone trap designs for monitoring corn earworm and tobacco budworm (Lepidoptera: Noctuidae). J. Econ. Entomol. 87:793-801.

Lopez, Jr., J.D., J.L. Goodenough, and K.R. Beerwinkle. 1994. Comparison of two sex pheromone trap designs for monitoring corn earworm and tobacco budworm (Lepidoptera: Noctuidae). J. Econ. Entomol. 87:793-801. 
Martin, P.B., P.D. Lingren, and G.L. Greene. 1976. Relative abundance and host preferences of cabbage looper, soybean looper, tobacco budworm, and corn earworm on crops grown in northern Florida. Environ. Entomol. 5:878-882.

Martin, P., P.D. Lingren, G.L. Greene, and E.E. Grissell. 1981. The parasitoid complex of three noctuids (Lep.) in a northern Florida cropping system: seasonal occurrence, parasitization, alternate hosts, and influence of host-habitat. Entomophaga 26:401-419.

Martin, P.B., P.D. Lingren, G.L. Greene, and R.L. Ridgway. 1976. Parasitization of two species of Plusiinae and Heliothis spp. after releases of Trichogramma pretiosum in seven crops. Environ. Entomol. 5:991-995.

Neunzig, H.H. 1963. Wild host plants of the corn earworm and the tobacco budworm in eastern North Carolina. J. Econ. Entomol. 56:135-139.

Neunzig, H.H. 1964. The eggs and early-instar larvae of Heliothis zea and Heliothis virescens (Lepidoptera: Noctuidae). Ann. Entomol. Soc. Am. 57:98-102.

Neunzig, H.H. 1969. The biology of the tobacco budworm and the corn earworm in North Carolina with particular reference to tobacco as a host. North Carolina Agric. Exp. Stn. Tech. Bull. 196. 76 pp.

Okumura, G.T. 1962. Identification of lepidopterous larvae attacking cotton with illustrated key (primarily California species). California Dept. Agric. Bur. Entomol. Spec. Publ. 282. 80 pp.

Oliver, A.D. and J.B. Chapin. 1981. Biology and illustrated key for the identification of twenty species of economically important noctuid pests. Louisiana Agric. Exp. Stn. Bull. 733. 26 pp.

Pair, S.D. 1994. Japanese honeysuckle (Caprifoliaceae): newly discovered host of Heliothis virescens and Helicoverpa zea (Lepidoptera: Noctuidae). Environ. Entomol. 23:906-911.

Roach, S.H. 1975. Heliothis spp.: larvae and associated parasites and diseases on wild host plants in the Pee Dee area of South Carolina. Environ. Entomol. 4:725-728.

Roltsch, W.J. and M.A. Mayse. 1984. Population studies of Heliothis spp. (Lepidoptera: Noctuidae) on tomato and corn in southeast Arkansas. Environ. Entomol. 13:292-299.

Snodgrass, G.L. and E.A. Stadelbacher. 1994. Population levels of tarnished plant bugs (Heteroptera: Miridae) and beneficial arthropods following early-season treatments of Geranium dissectum for control of bollworms and tobacco budworms (Lepidoptera: Noctuidae). Environ. Entomol. 23:1091-1096.

Stadelbacher, E.A. 1981. Role of early-season wild and naturalized host plants in the buildup of the F1 generation of Heliothis zea and H. virescens in the Delta of Mississippi. Environ. Entomol. 10:766-770.

Stone, T.B. and S.R. Sims. 1993. Geographic susceptibility of Heliothis virescens and Helicoverpa zea (Lepidoptera: Noctuidae) to Bacillus thuringiensis. J. Econ. Entomol. 86:989- 994.

Sudbrink, Jr., D.L. and J.F. Grant. 1995. Wild host plants of Helicoverpa virescens (Lepidoptera: Noctuidae) in eastern Tennessee. Environ. Entomol. 24:1080-1085.

Tingle, F.C., E.R. Mitchell, and J.R. McLaughlin. 1994. Lepidopterous pests of cotton and their parasitoids in a double-cropping environment. Florida Entomol. 77:334-341.

Tumlinson, J.H., D.E. Hendricks, E.R. Mitchell, R.E. Doolittle, and M.M. Brennan. 1975. Isolation, identification and synthesis of the sex pheromone of the tobacco budworm. J. Chem. Ecol. 1:203-214.

Vail, P.V., D.L. Jay, F.D. Stewart, A.J. Martinez, and H.T. Dulmage. 1978. Comparative susceptibility of Heliothis virescens and $H$. zea to the nuclear polyhedrosis virus isolated from Autographa californica. J. Econ. Entomol. 71:293-296. 